\title{
Organogenesis from leaf and internode explants of Ophiorrhiza prostrata, an anticancer drug (camptothecin) producing plant
}

A. Shahanaz Beegum

Department of Botany

University of Calicut

Kerala 673 635, India

Tel: 914942401144 Ext. 407

E-mail: marttinet@rediffmail.com

Kottackal Poulose Martin*

Department of Biotechnology

University of Calicut

Kerala 673 635, India

Tel: 914942401972

Fax: 914942400269

E-mail: marttinet@rediffmail.com

Chun-Lai Zhang

Norman Borlaug Institute for Plant Science Research

Faculty of Health and Life Sciences

De Montfort University

The Gateway, Leicester LE1 9BH, UK

Tel: 441162577719

Fax: 441162577290

E-mail: clzhang@dmu.ac.uk

\section{K. Nishitha}

Department of Botany

University of Calicut

Kerala 673 635, India

Tel: 914942401144 Ext. 407

E-mail: iknishitha@rediffmail.com

\section{Ligimol}

Department of Botany

University of Calicut

Kerala 673 635, India

Tel: 914942401144 Ext. 407

E-mail: marttinet@rediffmail.com

\section{Adrian Slater}

Norman Borlaug Institute for Plant Science Research

Faculty of Health and Life Sciences

De Montfort University

The Gateway, Leicester LE1 9BH, UK

Tel: 441162577843

Fax: 441162577290

E-mail: ads@dmu.ac.uk

\section{P. V. Madhusoodanan}

Department of Botany

University of Calicut

Kerala 673 635, India

Tel: 914942401144 Ext. 407

Fax: 914942400269

E-mail: madhuspv@sify.com

Keywords: camptothecin, medicinal plant, Ophiorrhiza prostrata, plant growth regulators.

*Corresponding author 


$\begin{array}{ll}\text { Abbreviations: } & \text { BA: } \mathrm{N}^{6} \text {-Benzyladenine } \\ & \text { CPT: camptothecin } \\ & \text { IAA: Indole-3-acetic acid } \\ & \text { IBA: Indole-3-butyric acid } \\ & \text { Kn: Kinetin } \\ & \text { MS: Murashige and Skoog } \\ \text { NAA: } \alpha \text {-Naphthaleneacetic acid } \\ \text { PGRs: plant growth regulators }\end{array}$

Camptothecin (CPT) analogues and derivatives serve as a novel class of effective anticancer agents that exert their action against DNA topoisomerase I. This paper presents procedures for the rapid, high frequency regeneration of a camptothecin producing plant, Ophiorrhiza prostrata D. Don from leaf and internode explants via shoot organogenesis. The concentrations of plant growth regulators and explant types exhibited discrete roles in the efficacy of shoot induction. $\mathrm{N}^{6}$ benzyladenine (BA) was the most effective cytokinin for the induction of shoots. Murashige and Skoog (MS) medium with $8.87 \mu \mathrm{M}$ BA and $2.46 \mu \mathrm{M}$ indole-3-butyric acid (IBA) yielded the highest number of shoots from leaf and internode explants (76.0 and 90.8 shoots respectively). In the case of leaf explants, explants from the proximal end produced a higher number of shoots than those from the mid and distal end. Leaf and internode explants cultured on MS medium supplemented with $\alpha$-naphthaleneacetic acid (NAA) and BA developed shoots, calli and roots. Calli subcultured onto medium supplemented with $8.87 \mu \mathrm{M} B A$ and 2.46 $\mu M$ IBA developed a mean of 20.1 shoots within 40 days. Excision and culture of internode and proximal leaf explants from the established cultures on MS basal medium significantly enhanced the number of shoots and yielded a mean of 18.3 and 13.7 shoots respectively within 40 days. Histological examination of leaf explants showed that the shoots were of sub-epidermal origin, confined to the sub-epidermal cells above the vascular traces. Shoots cultured on half-strength MS basal medium with $10.74 \mu \mathrm{M}$ NAA and $2.32 \mu \mathrm{M}$ Kn produced a mean of 48.2 roots per shoot. Direct transfer of rootless healthy shoots showed a $\mathbf{5 0 \%}$ survival rate, whilst it was 100 percent in the case of in vitro rooted shoots.

Camptothecin (CPT), isolated and characterized for the first time by Wall et al. (1966), is a monoterpene indole alkaloid originally derived from Camptotheca acuminata (Nyssaceae), a native of North China. Members of the Icacinaceae, Olacaceae, Rubiaceae, and Apocynaceae families are also reported to produce camptothecin. CPT analogues and derivatives are a novel class of effective anticancer agents that exert their action against DNA topoisomerase (topo) I (Redinbo et al. 1998). The worldwide market size of camptothecin derivatives (e.g. topotecan and irinotecan) reached 1.5 billion US dollars in 2002 (Lorence and Nessler, 2004). Due to the cytotoxicity of camptothecin itself, the CPT derivatives, irinotecan and topotecan, are used throughout the world for the treatment of various cancers, and over a dozen or more CPT analogues are currently at various stages of clinical development (Lorence et al. 2004). However, they are synthesized from natural camptothecin which is extracted from plants. The use of CPTs as inhibitors of replication, transcription, and packing of double stranded DNAcontaining adenoviruses, papovaviruses, and the singlestranded DNA-containing autonomous parvoviruses has been studied (Pantazis et al. 1999). It appears that CPTs could be powerful antiviral drugs for several DNA viruses, which are causative agents for a large number of diseases. Since 1994, CPT has been in use clinically in Japan for the treatment of lung, ovarian and uterine cancer (Japan Pharmaceutical Information Center, 1995). It has also proved useful as an insect chemosterilant and plant growth regulator and as an inhibitor of herpes virus (Becker and Olshevsky, 1973). The therapeutic values of CPT derivatives are highlighted against colon cancer (Giovanella et al. 1989), AIDS (Priel et al. 1991), uterine cervical and ovarian cancer (Takeuchi et al. 1991), and falciparum malaria (Bodley et al. 1998).

The genus Ophiorrhiza belongs to the family Rubiaceae, which comprises 150 species. The roots of Ophiorrhiza species, $O$. mungos and $O$. pumila have been reported as the sources of CPT and 10-methoxycamptothecin (Tafur et al. 1976; Saito et al. 2001; Sudo et al. 2002; Watase et al. 2004). The Ophiorrhiza spp. is also used to provide remedies for ulcers, helminthiasis, snake poison, poisonous wounds, gastropathy, leprosy, and hydrophobia (Kirtikar and Basu, 1975). O. prostrata D. Don is an herbaceous perennial medicinal plant, exploited for the production of camptothecin, which is accumulated mainly in the roots. A comparative study of camptothecin content in Nothapodytes foetida, O. mungos and O. rugosa indicated highest yields of camptothecin and 9-methoxy camptothecin in N. foetida (Roja, 2006).

The rate of plant propagation is critical to meet the pharmaceutical demand for camptothecin. A slow propagation rate in $O$. prostrata, because of low seed viability and germination rate as well as a small number of propagules (stem cuttings), has restricted the natural dissemination of the plant. In addition, the destruction caused by harvesting the roots as a source of the drug has threatened the survival of the plant. Thus, the large-scale demand necessitates rapid multiplication of the plant within 
Table 1. Direct organogenesis from internode and proximal leaf explants of 0 . prostrata on MS media with various plant growth regulators. Data represents the mean of 20 replicates. Mean values followed by the same letters within columns are not significantly different at the $5 \%$ level. Culture duration was 40 days.

\begin{tabular}{|c|c|c|c|c|c|c|c|}
\hline \multicolumn{4}{|c|}{$\begin{array}{l}\text { Plant Growth regulators } \\
\qquad(\mu \mathrm{M})\end{array}$} & \multicolumn{2}{|c|}{$\begin{array}{l}\text { Percentage of explants } \\
\text { forming shoots }\end{array}$} & \multicolumn{2}{|c|}{$\begin{array}{l}\text { Number of shoots } \\
\text { per explant }\end{array}$} \\
\hline BA & $\mathrm{Kn}$ & NAA & IBA & Leaf & Internode & Leaf & Internode \\
\hline 0 & 0 & 0 & 0 & 80 & 90 & $2.9^{m}$ & $4.0^{\prime}$ \\
\hline 2.22 & & & & 80 & 85 & $8.4^{\mathrm{k}}$ & $12.3^{j}$ \\
\hline 4.44 & & & & 95 & 100 & $13.8^{j}$ & $25.9^{9}$ \\
\hline 6.66 & & & & 100 & 100 & $21.4^{g}$ & $35.1^{\mathrm{e}}$ \\
\hline 8.87 & & & & 100 & 100 & $38.0^{d}$ & $51.5^{d}$ \\
\hline 13.3 & & & & 100 & 100 & $30.4^{\mathrm{e}}$ & $36.5^{\mathrm{e}}$ \\
\hline 17.7 & & & & 100 & 100 & $25.0^{f}$ & $29.3^{f}$ \\
\hline \multirow[t]{5}{*}{22.2} & & & & 100 & 100 & $13.4^{j}$ & $17.6^{\mathrm{h}}$ \\
\hline & 2.32 & & & 90 & 95 & $4.1^{1}$ & $6.2^{k}$ \\
\hline & 4.65 & & & 100 & 100 & $19.1^{\mathrm{g}}$ & $27.0^{\mathrm{fg}}$ \\
\hline & 6.97 & & & 100 & 100 & $16.2^{\mathrm{i}}$ & $18.6^{\mathrm{h}}$ \\
\hline & 9.29 & & & 100 & 100 & $7.5^{\mathrm{k}}$ & $14.7^{i}$ \\
\hline 8.87 & 0.46 & & & 100 & 100 & $24.5^{f}$ & $29.5^{f}$ \\
\hline 8.87 & 2.32 & & & 100 & 100 & $21.3^{g}$ & $24.3^{g}$ \\
\hline 8.87 & 4.65 & & & 100 & 100 & $16.1^{i}$ & $21.5^{\mathrm{h}}$ \\
\hline 8.87 & & 0.54 & & 100 & 100 & $29.3^{\mathrm{e}}$ & $35.6^{\mathrm{e}}$ \\
\hline 8.87 & & 2.69 & & 100 & 100 & $24.5^{f}$ & $28.8^{f}$ \\
\hline 8.87 & & 5.37 & & 100 & 100 & $19.2^{\mathrm{g}}$ & $24.1^{9}$ \\
\hline 8.87 & & & 0.49 & 100 & 100 & $47.5^{\mathrm{b}}$ & $61.0^{b}$ \\
\hline 8.87 & & & 2.46 & 100 & 100 & $76.0^{\mathrm{a}}$ & $90.8^{a}$ \\
\hline 8.87 & & & 4.90 & 100 & 100 & $40.7^{c}$ & $56.1^{c}$ \\
\hline
\end{tabular}

a short timeframe without a negative impact on the natural resources. In vitro morphogenesis without a callus phase is regarded as the most faithful strategy to obtain plants with high speed as well as genetic fidelity. Direct shoot induction as an easy way for the rapid plant propagation has been reported in several medicinal plants viz. Murraya koeningii (Rout, 2005), and Euphorbia nivulia (Martin et al. 2005). Micropropagation of $O$. mungo by using seedling shoot culture has been reported (Jose and Satheeshkumar, 2004). Callus mediated plant regeneration is an easy way to obtain somaclonal variants as has been emphasized in several plants (Dennis and Boban, 2005; Dhar and Joshi, 2005; Faisal and Anis, 2005; Agrawal and Sardar, 2006). So far, no protocol for in vitro propagation of $O$. prostrata 
has been published. The propagation of $C$. acuminata conventionally as well as through in vitro culture is not as easy as that of herbs such as $O$. prostrata. This study establishes rapid propagation protocols using leaf and internode explants in order to meet the demand, which could curtail the impact on the natural population and prevent the plant from becoming endangered.

\section{MATERIALS AND METHODS}

Healthy young shoots of $O$. prostrata were collected from potted plants and used as the starting material. Young leaves and internode segments were washed separately under running tap water followed by $5 \%(\mathrm{v} / \mathrm{v})$ solution of Extran (a neutral liquid detergent, Merck India Ltd., Mumbai) for $5 \mathrm{~min}$ followed by surface sterilization using $0.1 \% \quad(\mathrm{w} / \mathrm{v})$ mercuric chloride. Leaf segments were sterilized for 7-9 min, while internode segments were treated for 10-12 min. Decanting of the mercuric chloride was followed by repeated washes ( 3 times 5 min each) in sterile water. The sterilized tissues were cut into appropriate sizes (leaf explants of $10 \mathrm{~mm}^{2}$ and internode of 7-15 mm) using sterile forceps and knife. For the induction of direct shoot formation, the explants were cultured on MS
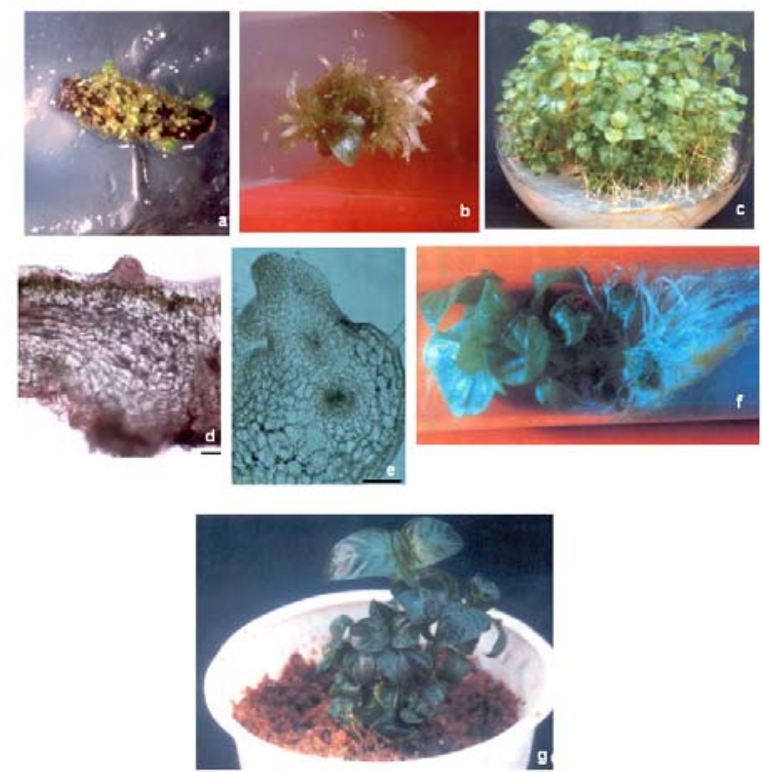

Figure 1. In vitro propagation of 0 . prostrata through direct organogenesis.

(a) Shoots from internode explants on MS medium with 8.87 $\mu \mathrm{M}$ BA and $2.46 \mu \mathrm{M}$ IBA.

(b) Shoots from leaf explants on MS medium with $8.87 \mu \mathrm{M}$ BA and 2.46 $\mu \mathrm{M}$ IBA.

(c) Shoot multiplication on the above medium during subculture.

(d) Shoot origin from sub-epidermal cells of leaf explants (bar $=0.1 \mathrm{~mm}$ ).

(e) Shoot origin from sub-epidermal cells of internode explants (bar $=0.1 \mathrm{~mm}$ ).

(f) Rooted shoot on half-strength MS medium with $10.74 \mathrm{mM}$ NAA and $2.32 \mathrm{mM} \mathrm{Kn}$.

(g) Established plant (after 45 days).
(Murashige and Skoog, 1962) medium supplemented with different levels of plant growth regulators (Table 1). Subcultures were carried out on MS medium with various concentrations of plant growth regulators (PGRs) as specified in the text. For indirect organogenesis and in vitro rooting MS media supplemented with different PGRs were used as shown respectively in Table 2 and Table 3 . Test tubes $(25 \times 200 \mathrm{~mm}), 100 \mathrm{ml}$ conical flasks, and jam bottles (53 x $125 \mathrm{~mm} ; 2 \mathrm{~mm}$ thick) were used as culture vessels. Test tubes and conical flasks were closed by cotton plugs, while jam bottles were capped with polypropylene autoclavable lids (14 mm height x $48 \mathrm{~mm}$ inner diameter with $2 \mathrm{~mm}$ thick). The media were adjusted to $\mathrm{pH} 5.8$, and were solidified with $0.8 \%(\mathrm{w} / \mathrm{v})$ agar. They were sterilized at a pressure of $1.06 \mathrm{~kg} \mathrm{~cm}^{-2}$ at $121^{\circ} \mathrm{C}$ for $20 \mathrm{~min}$ in an autoclave. All cultures were incubated at $25 \pm 2^{\circ} \mathrm{C}$ with 16 hrs light (at an irradiance of $25 \mu \mathrm{mol} \mathrm{m}^{-2} \mathrm{~s}^{-1}$ )/8 h dark cycle under white fluorescent tubes.

Ontogeny of shoot induction was studied by taking random sections at different growth stages. Sections were stained with a dilute solution of safranin and observed under a Leitz Dialux 20 (Germany) microscope.

Plantlets (derived through in vitro rooting) as well as wellgrown shoots without roots (ex vitro rooting) from the shoot multiplication medium were transferred to small pots containing soil and sand (1:1), covered with moistened polyethylene bags and kept at room temperature $\left(33 \pm 2^{\circ} \mathrm{C}\right)$ for acclimation, and subsequently transferred to field conditions.

The experiments were performed in a completely randomized design. Twenty replicates were used for each treatment, and all the treatments were repeated twice for confirmation. The mean values of different treatments were analyzed using Duncan's multiple range test.

\section{RESULTS}

\section{Direct organogenesis}

Leaf and internode explants cultured on MS basal medium produced directly a mean of 2.9 and 4.0 shoots respectively. Addition of PGRs induced shoot formation and the number of shoots depended on the types and concentrations of PGRs, BA in particular (Table 1) as well as the explant types. MS medium containing BA alone was superior to that containing $\mathrm{Kn}$ alone for the induction of shoots (Table 1). On medium with $8.87 \mu \mathrm{M} \mathrm{BA}$, internode explants developed a mean of 51.5 shoots, while the proximal leaf explants produced a mean of 38.0 shoots within 40 days. Upon medium with $8.87 \mu \mathrm{M}$ BA, leaf explants initiated shoots within 14 days, while the internode explants induced shoots within 12 days. Lower concentrations of BA induced callus with a reduction in number of shoots. Higher levels of BA increased the amount of callus. The calli later developed shoot buds. Increasing BA concentrations above $8.87 \mu \mathrm{M}$ exhibited a negative effect on the height of shoots 
Table 2. Organogenesis from callus on MS medium with different plant growth regulators. Data represents the mean of 20 replicates. Mean values followed by different letters are significantly different at $5 \%$ level. Culture duration was 40 days.

\begin{tabular}{|c|c|c|c|c|}
\hline \multicolumn{3}{|c|}{ Plant Growth regulators ( $\mu$ M) } & $\begin{array}{c}\text { Number of shoots per } \\
\text { culture }\end{array}$ \\
\hline BA & Kn & NAA & IBA & $5.5^{\mathrm{f}}$ \\
\hline 4.44 & & & & $8.3^{\mathrm{e}}$ \\
\hline 6.66 & & & & $15.7^{\mathrm{b}}$ \\
\hline 8.87 & & & & $8.0^{\mathrm{e}}$ \\
\hline 13.31 & & & & $11.6^{\mathrm{c}}$ \\
\hline 8.87 & 0.46 & & & $7.9^{\mathrm{e}}$ \\
\hline 8.87 & 2.32 & & & $10.6^{\mathrm{d}}$ \\
\hline 8.87 & & 0.54 & & $9.9^{\mathrm{d}}$ \\
\hline 8.87 & & 2.69 & & $14.9^{\mathrm{b}}$ \\
\hline 8.87 & & & 0.49 & $20.1^{\mathrm{a}}$ \\
\hline 8.87 & & & 2.46 & $12.7^{\mathrm{c}}$ \\
\hline 8.87 & & & 4.90 & \\
\hline
\end{tabular}

i.e., the shoot height decreased as BA concentrations increased. Kn containing media favoured better shoot elongation than that on BA alone supplemented media, and the shoots on medium having $\mathrm{Kn}$ attained $>3 \mathrm{~cm}$ height within 40 days. On Kn fortified media, unlike that on BA containing media, the explants as well as the regenerated shoots produced roots as well. Combinations of BA and $\mathrm{Kn}$ at different concentrations displayed less numbers of shoots than media with $8.87 \mu \mathrm{M}$ BA (Table 1).

Synergy between BA and auxins exhibited a positive effect in the induction of shoots. MS medium with $8.87 \mu \mathrm{M}$ BA and $2.46 \mu \mathrm{M}$ IBA developed the highest number of shoots; 76.0 and 90.8 shoots from leaf and internode explants respectively (Table 1; Figure 1a and Figure 1b). As on medium with other PGRs, the shoots on leaf explants were developed adaxially, however, with a few shoots on the abaxial side. Of the different regions in the leaf, explants from proximal region were superior in the induction of shoots. Increasing IBA concentration favoured callus induction especially from the cut ends of explants, which later regenerated into shoots. The shoots were longer on media containing BA and auxins than those in media containing BA alone. The regenerated shoots developed roots following further culture. The combination of BA and NAA was inferior for shoot formation (Table 1) but facilitated the formation of a higher amount of callus.
Direct organogenesis is regarded as the most reliable method for clonal propagation because it upholds genetic uniformity among the progenies. As in the present study, direct formation of shoots without an exogenous trigger has been reported in different explants/species, e.g. from internodes of Bacopa monniera (Tiwari et al. 1998; Shrivastava and Rajani, 1999), and leaf explants of Drosera binata (Kawiak et al. 2003). Watase et al. (2004) has reported spontaneous formation of shoots from hairy roots of Ophiorrhiza pumila. The development of shoots on basal media may be due to stimulation by endogenous hormones or some signals related to wounding, which play a vital role during the induction of regeneration, or the ratio of ions present in the medium. The difference in the number of shoots formed in leaf and internode explants may be a result of differences in the regeneration potential of different explants, which is attributed by the physiological state, age and cellular differentiation among the constituent cells (Murashige, 1974). Enhancement in the induction of shoots by the synergy of BA and auxins observed in the present study has been documented in Stevia rebaudiana (Sivaram and Mukundan, 2003), Aloe vera (Liao et al. 2004), Murraya koeningii (Rout, 2005) and Euphorbia nivulia (Martin et al. 2005). Nevertheless, adventitious shoot regeneration has been accomplished with a mean 10.4 of shoots per shoot explants of Ophiorrhiza mungo cultured on MS medium with $2.22 \mu \mathrm{M}$ BA (Jose and 
Satheeshkumar, 2004). Though Kn was inferior for shoot formation in $O$. prostrata, efficacy of $\mathrm{Kn}$ or other cytokinins either alone or in combination with $\mathrm{BA} /$ auxins in direct shoot formation has been demonstrated in Asparagus maritimus (Stajner et al. 2002), Robinia pseudoacacia (Shu et al. 2003), and Bixa orellana (De Paiva et al. 2003).

High shoot regeneration potential of proximal end explants as to leaf tip explants as in the present study has been emphasized in Beta vulgaris (Zhang et al. 2001), Anthurium andraeanum cultivars Tinora Red and Senator (Martin et al. 2003), and Euphorbia nivulia (Martin et al. 2005). In the view of Welander (1988), the high potential of the proximal end to the distal may be due to the difference in the maturity between proximal and distal end of the leaf, and which is supported by the fact that leaves reach maturity first at distal (tip) and subsequently in a basipetal progression. High frequency shoot induction at the proximal region may also be due to the higher level of IAA and abscisic acid (Rajasekharan et al. 1987).

\section{Callus induction}

Leaf and internode explants cultured on MS media with different levels of NAA either alone or in combination with BA or Kn produced calli, roots, and shoots $(<4)$ (data not shown). MS medium with $5.37 \mu \mathrm{M}$ NAA alone induced a mean fresh weight of 219 and $188 \mathrm{mg}$ calli per explants respectively from internode and leaf explants. Combinations of NAA with BA or Kn favoured increased numbers of shoots along with callus formation. MS medium with $5.37 \mu \mathrm{M}$ NAA and $2.22 \mu \mathrm{M}$ BA induced the highest amount of callus ( 310 and $295 \mathrm{mg}$ from internode and leaf respectively) with $<6$ shoots. The calli developed were pale green to dark green and semi-hard.

\section{Indirect organogenesis}

Callus initiated on MS medium with NAA alone or in combination with $\mathrm{BA}$ or $\mathrm{Kn}$ upon subculture developed adventitious shoots. MS medium with $8.87 \mathrm{M}$ BA and 2.46 $\mu \mathrm{M}$ IBA was the best with a mean of 20.1 shoots within 40 days (Table 2). Increasing the concentration of BA prevented elongation of shoots. Higher concentrations of BA favoured callus proliferation and subsequent culture of the callus favoured better shoot morphogenesis. Callus mediated shoot morphogenesis has been well accomplished in several medicinal plants: Tylophora indica (Dennis and

Table 3. Efficacy of half strength MS medium with different plant growth regulators in the induction of roots on in vitro-derived shoots. Data represents the mean of 20 replicates. Mean values followed by different letters are significantly different at $5 \%$ level. Culture duration was 40 days.

\begin{tabular}{|c|c|c|c|c|c|}
\hline \multicolumn{7}{|c|}{ Plant Growth regulators $(\mu \mathrm{M})$} & Percentage of shoots producing roots & \\
\hline NAA & IBA & IAA & Kn & 95 & $3.8^{\mathrm{i}}$ \\
\hline 0 & 0 & 0 & 0 & 95 & $5.9^{\mathrm{h}}$ \\
\hline 0.54 & & & & 100 & $19.1^{\mathrm{d}}$ \\
\hline 2.69 & & & & 100 & $35.1^{\mathrm{b}}$ \\
\hline 5.37 & & & & 95 & $4.3^{\mathrm{hi}}$ \\
\hline & 0.49 & & & 100 & $12.1^{\mathrm{e}}$ \\
\hline & 2.46 & & & 100 & $10.6^{\mathrm{f}}$ \\
\hline & 4.90 & & & 95 & $5.0^{\mathrm{h}}$ \\
\hline & & 0.57 & & 100 & $13.4^{\mathrm{e}}$ \\
\hline & & 2.85 & & 100 & $11.6^{\mathrm{f}}$ \\
\hline & & 5.71 & & 95 & $8.8^{\mathrm{g}}$ \\
\hline & & & 4.65 & 100 & $48.2^{\mathrm{a}}$ \\
\hline 10.74 & & & 2.32 & 100 & $26.3^{\mathrm{c}}$ \\
\hline 10.74 & & & 4.65 & & \\
\hline
\end{tabular}


Boban, 2005; Faisal and Anis, 2005), Saussurea obvallata (Dhar and Joshi, 2005) and Euphorbia nivulia (Sunandakumari et al. 2005) and Cassia angustifolia (Agrawal and Sardar, 2006). High frequency callus mediated shoot regeneration can be utilised for the induction of somaclonal variation for the improvement of this valuable medicinal plant.

\section{Shoot multiplication}

The internode and leaf explants derived from established in vitro cultures on MS basal medium produced high numbers of shoots with means of 18.3 and 13.7 respectively. A high yield of shoots was achieved by culturing stem and leaf (proximal) segments as well as shoot clumps excised from the primary cultures on medium optimal for direct shoot multiplication (MS medium with $8.87 \mu \mathrm{M}$ BA and $2.46 \mu \mathrm{M}$ IBA). The number of shoots developed was difficult to count and was further increased in subsequent cultures (Figure 1c). The shoots cultured on MS medium without PGRs developed long shoots with roots. The roots turned to reddish brown from white through golden yellow. The colour of the roots may be due to the accumulation of secondary metabolites (CPT and its derivatives).

\section{Ontogeny of shoots}

The shoots were initiated from sub-epidermal cells especially from the region above the vascular bundles of the explants (Figure 1d and Figure 1e). Both palisade and spongy cells developed shoots. The shoots were shown to contain an extension of the vascular bundles from the source tissue. In the case of leaf explants, the shoots originated from subepidermal cells above the vascular traces. Shoots originating from subepidermal cells have been reported in tobacco stem explants (CreemersMolenaar et al. 1994). The ability of different tissues to form shoots directly in other species has been demonstrated including leaf epidermis (Lo et al. 1997), vascular cambium (Wenzel and Brown, 1991), cortex (Arai et al. 1997) and cortical, subcortical (Twyford and Mantell, 1996) or epidermis or cortex of root (Knoll et al. 1997).

\section{Rooting}

In vitro as well as ex vitro root induction was preceded by transfer of healthy shoots with more than $3.0 \mathrm{~cm}$ height grown in the shoot induction or shoot multiplication medium to rooting media or soil. Shoots transferred to halfstrength MS medium free of PGRs induced more roots than those on full-strength MS medium. Auxins at lower concentrations, supplemented to half-strength MS medium induced a large number of roots (Table 3). Of the different auxins, NAA at $5.37 \mu \mathrm{M}$ was superior, which induced a mean of 35.1 roots per shoot within 30 days. Auxins also facilitated callus formation in a small number of shoots. The callus developed roots later. Shoots cultured on halfstrength MS medium with $4.65 \mu \mathrm{M} \mathrm{Kn}$ alone also induced roots (Table 3 ). Addition of $\mathrm{Kn}$ to auxin containing medium augmented root induction. MS medium with high concentration of NAA and $\mathrm{Kn}$ favoured better in vitro rooting than with auxins alone. Half-strength MS medium containing $10.74 \mu \mathrm{M}$ NAA and $2.32 \mu \mathrm{M}$ Kn produced a mean of 48.2 roots per shoot (Figure 1f). Increased rooting by the addition of cytokinins has been emphasized in Drosera cunefolia (Kawiak et al. 2003). However, Jose and Satheeshkumar (2004) observed the best in vitro rooting in Ophiorrizha mungo on medium with IBA $(12.3 \mu \mathrm{M})$ plus NAA $(1.07 \mu \mathrm{M})$. The roots developed on all media became reddish brown through golden yellow from white. The high numbers of roots produced under optimal plant growth regulator regimes opens the possibility of producing camptothecin as the root is the main source for the chemicals.

Transfer of rootless shoots directly into pots containing sand and soil (ex vitro rooting) resulted in a survival rate of $50 \%$ shoots. The shoots resumed growth after 15 days of transplantation. Ex vitro rooting may reduce the micropropagation cost and also the time from laboratory to field. Rooting extra vitrum has been reported in Rotula aquatica (Martin, 2003a), Eupatorium triplinerve (Martin, 2003b) and Prunus spp. (Pruski et al. 2005). In the present study, ex vitro shoots exhibited only $50 \%$ survival. Liu and Li (2001) noticed a high survival rate of plantlets through ex vitro propagation. This study showed ex vitro rooting gave a lower percentage of survival than in vitro rooting though ex vitro rooting looks promising considering the reduction in cost by avoiding the in vitro rooting and use of auxins and the reduction in labour and time of plantlet establishment from laboratory to land.

Plantlets derived after in vitro rooting showed $100 \%$ survival in field conditions. The plantlets transferred revived growth after 9 days and grew well (Figure 1g). The field established plants were identical in morphology and growth pattern to that of source plant.

The protocol described in this study enables production of more than 75 plants within two months using single internode explant. This may realize the demand of pharmaceutical industries and minimize the impact of over exploitation of the plants. Besides the propagation of elite cultivars and conservation of this rare medicinal plant, a highly efficient regeneration protocol opens a way for improvement of the plant through genetic transformation strategies.

\section{REFERENCES}

AGRAWAL, V. and SARDAR, P.R. In vitro propagation of Cassia angustifolia through leaflet and cotyledon derived calli. Biologia Plantarum, March 2006, vol. 50, no. 1, p. 118-122.

ARAI, M.; SAITO, T.; KANEKO, Y. and MATSUSHIMA, $\mathrm{H}$. Cellular origin and ultrastructural changes of regenerating shoots from tobacco (Nicotiana tabacum) 
internodes cultured in vitro. Physiologia Plantarum, April 1997, vol. 99, no. 4, p. 523-528.

BECKER, Y. and OLSHEVSKY, U. Inhibition of herpes simplex virus replication by camptothecin. Israel Journal of Medical Sciences, 1973, vol. 9, no. 11-12, p. 1578-1581.

BODLEY, Annette L.; CUMMING, Jared N. and SHAPIRO, Theresa A. Effects of camptothecin, a topoisomerase I inhibitor, on Plasmodium falciparum. Biochemical Pharmacology, March 1998, vol. 55, no. 5, p. 709-711.

CREEMERS-MOLENAAR, J.; HAKKERT, J.C.; VAN STAVEREN, M.J. and GILISSEN, L.J.W. Histology of the morphogenetic response in thin cell layer explants from vegetative tobacco plants. Annals of Botany, May 1994, vol. 73 , no. 5, p. 547-555.

DE PAIVA NETO, Vespasiano Borges; DA MOTA, Tiago Ribeiro and OTONI, Wagner Campos. Direct organogenesis from hypocotyl-derived explants of annatto (Bixa orellana). Plant Cell, Tissue and Organ Culture, November 2003, vol. 75, no. 2, p. 159-167.

DENNIS, Thomas T. and BOBAN, Philip. Thidiazuroninduced high-frequency shoot organogenesis from leafderived callus of a medicinal climber, Tylophora indica (Furm. f.) Merrill. In Vitro Cellular and Development Biology - Plant, March-April 2005, vol. 41, no. 2, p. 124128.

DHAR, Uppeandra and JOSHI, Mitali. Efficient plant regeneration protocol through callus for Saussurea obvallata (DC.) Edgew. (Asteraceae): effect of explant type, age and plant growth regulators. Plant Cell Reports, June 2005, vol. 24, no. 4, p. 195-200.

FAISAL, M. and ANIS, M. An efficient in vitro method for mass propagation of Tylophora indica. Biologia Plantarum, June 2005, vol. 49, no. 2, p. 257-260.

GIOVANELLA, B.C.; STEHLIN, J.S.; WALL, M.E.; WANI, M.C.; NICHOLAS, A.W.; LIU, L.F.; SILBER, R. and POTMESIL, M. DNA topoisomerase I-targeted chemotherapy of human colon cancer in xenografts. Science, November 1989, vol. 246, no. 4933, p. 1046-1048.

JAPAN PHARMACEUTICAL INFORMATION CENTER. Drugs in Japan, Ethical Drugs. Yakugyo Jiho Co.; Tokyo, 1995, 169-270 p.

JOSE, B. and SATHEESHKUMAR, K. In vitro mass multiplication of Ophiorrhiza mungo Linn. Indian Journal of Experimental Biology, June 2004, vol. 42, no. 6, p. 639642 .

KAWIAK, Anna; KROLICKA, Aleksandra and LOJKOWSKA, Ewa. Direct regeneration of Drosera from leaf explants and shoot tips. Plant Cell, Tissue and Organ Culture, November 2003, vol. 75, no. 2, p. 175-178.

KIRTIKAR, K.R. and BASU, B.D. Indian Medicinal Plants Vol. II. $2^{\text {nd }}$ ed. M/S Bishen Singh Mahendrapal Singh, New Delhi, India, 1975. p. 1268-1269.

KNOLL, K.A.; SHORT, K.C.; CURTIS, I.S.; POWER, J.B. and DAVEY, M.R. Shoot regeneration from cultured root explants of spinach (Spinacia oleracea L.): a system for Agrobacterium transformation. Plant Cell Reports, December 1997, vol. 17, no. 2, p. 96-101.

LIAO, Zhihua; CHEN, Min; TAN, Feng; SUN, Xiaofen and TANG, Kexuan. Micropropagation of endangered Chinese aloe. Plant Cell, Tissue and Organ Culture, January 2004, vol. 76, no. 1, p. 83-86.

LIU, Z. and LI, Z. Micropropagation of Camptotheca acuminata decaisne from axillary buds, shoot tips, and seed embryos in a tissue culture system. In Vitro Cellular and Development Biology - Plant, January 2001, vol. 37, no. 1, p. 84-88.

LO, K.H.; GILES, K.L. and SAWHNEY, V.K. Histological changes associated with acquisition of competence for shoot regeneration in leaf discs of Saintpaulia ionantha $\mathrm{X}$ confusa hybrid (African violet) cultured in vitro. Plant Cell Reports, March 1997, vol. 16, no. 6, p. 421-425.

LORENCE, Argelia and NESSLER, Craig L. Camptothecin, over four decades of surprising findings. Phytochemistry, October 2004, vol. 65, no. 20, p. 27352749.

LORENCE, Argelia; MEDINA-BOLIVAR, F. and NESSLER, Craig L. Camptothecin and 10hydroxycamptothecin from Camptotheca acuminata hairy roots. Plant Cell Reports, January 2004, vol. 22, no. 6, p. 437-441.

MARTIN, K.P. Rapid in vitro multiplication and ex vitro rooting of Rotula aquatica Lour., a rare rhoeophytic woody medicinal plant. Plant Cell Reports, January 2003a, vol. 21, no. 5, p. 415-420.

MARTIN, K.P. Rapid axillary bud proliferation and ex vitro rooting of Eupatorium triplinerve. Biologia Plantarum, December 2003b, vol. 47, no. 4, p. 589-591.

MARTIN, K.P.; JOSEPH, D.; MADASSERY, J. and PHILIP, V.J. Direct shoot regeneration from lamina explants of two commercial cut flower cultivars of Anthurium andraeanum Hort. In Vitro Cellular and Development Biology - Plant, September-October 2003, vol. 39 , no. 5, p. 500-504.

MARTIN, K.P.; SUNANDAKUMARI, C.; CHITHRA, M. and MADHUSOODANAN, P.V. Influence of auxins in direct in vitro morphogenesis of Euphorbia nivulia, a 
lectinacious medicinal plant. In Vitro Cellular and Development Biology - Plant, May-June 2005, vol. 41, no. 3, p. 314-319.

MURASHIGE, T. and SKOOG, F. A revised medium for rapid growth and bioassays with tobacco tissue cultures. Physiologia Plantarum, October 1962, vol. 15, no. 43, p. 473-497.

MURASHIGE, T. Plant propagation through tissue cultures. Annual Review of Plant Physiology, June 1974, vol. 25, p.135-166.

PANTAZIS, Panayotis; HAN, Zhiyong; CHATTERJEE, Devasis and WYCHE, James. Water-insoluble camptothecin analogues as potential antiviral drugs. Journal of Biomedical Science, January 1999, vol. 6, no. 1, p. 1-7.

PRIEL, E.; SHOWALTER, S.D. and BLAIR, D.G. Inhibition of human immunodeficiency virus (HIV-1) replication in vitro by noncytotoxic doses of camptothecin, a topoisomerase I inhibitor. AIDS Research and Human Retroviruses, 1991, vol. 7, no. 1, p. 65-72.

PRUSKI, Kris; ASTATKIE, Tess and NOWAK, Jerzy. Tissue culture propagation of Mongolian cherry (Prunus fruticosa) and Nanking cherry (Prunus tomentosa). Plant Cell, Tissue and Organ Culture, August 2005, vol. 82, no. 2, p. 207-211.

RAJASEKHARAN, K.; HEIN, M.B.; DAVIS, G.C.; CARNES, M.G. and VASIL, I.K. Endogenous growth regulators in leaves and tissue cultures of Pennisetum purpureum Schum. Journal of Plant Physiology, 1987, vol. 130, no. 1, p.13-25.

REDINBO, Matthew R.; STYEWART, Lance; KUHN, Peter; CHAMPOUX, James J. and HOL, Wim G.J. Crystal structures of human topoisomerase I in covalent and monocovalent complexes with DNA. Science, March 1998, vol. 279 , no. 5356, p. 1504-1513.

ROJA, G. Comparative studies on the camptothecin content from Nothapodytes foetida and Ophiorrhiza species. Natural Product Research, January 2006, vol. 20, no. 1, p. 85-88.

ROUT, Gyana Ranjan. Direct plant regeneration of curry leaf tree (Murraya koenigii Koenig.), an aromatic plant. In Vitro Cellular and Development Biology - Plant, MarchApril 2005, vol. 41, no. 2, p. 133-136.

SAITO, K.; SUDO, H.; YAMAZAKI, M.; KOSEKINAKAMURA, M.; KITAJIMA, M.; TAKAYAMA, H. and AIMI, N. Feasible production of camptothecin by hairy root cultures of Ophiorrhiza pumila. Plant Cell Reports, March 2001, vol. 20, no. 3, p. 267-271.
SHRIVASTAVA, N. and RAJANI, M. Multiple shoot regeneration and tissue culture studies on Bacopa monnieri (L.) Pennell. Plant Cell Reports, August 1999, vol. 18, no. 11, p. 919-923.

SHU, Q.Y.; LIU, G.S.; QI, D.M.; CHU, C.C.; LIU, J. and LI, H.J. An effective method for axillary bud culture and RAPD analysis of cloned plants in tetraploid black locust. Plant Cell Reports, October 2003, vol. 22, no. 3, p. 175180.

SIVARAM, Latha and MUKUNDAN, Usha. In vitro culture studies on Stevia rebaudiana. In Vitro Cellular and Development Biology - Plant, September-October 2003, vol. 39 , no. 5 , p. $520-523$.

ŠTAJNER, Nataša; BOHANEC, Borut and JAKŠE, Marijana. In vitro propagation of Asparagus maritimus - A rare Mediterranean salt-resistant species. Plant Cell, Tissue and Organ Culture, September 2002, vol. 70, no. 3, p. 269274.

SUDO, Hiroshi; YAMAKAWA, Takashi; YAMAZAKI, Mami; AIMI, Norio and SAITO, Kazuki. Bioreactor production of camptothecin by hairy root cultures of Ophiorrhiza pumila. Biotechnology Letters, March 2002, vol. 24 , no. 5, p. 359-363.

SUNANDAKUMARI, C.; ZHANG, C.-L.; MARTIN, K.P.; SLATER, A. and MADHUSOODANAN, P.V. Effect of auxins on indirect in vitro morphogenesis and expression of gusA transgene in a lectinacious medicinal plant, Euphorbia nivulia Buch.-Ham. In Vitro Cellular and Development Biology - Plant, September-October 2005, vol. 41, no. 5, p. 695-699.

TAFUR, S.; NELSON, J.D.; DELONG, D.C. and SVOBODA, G.H. Antiviral components of Ophiorrhiza mungos isolation of camptothecin and 10methoxycamptothecin. Lloydia, 1976, vol. 39, no. 4, p. 261262.

TAKEUCHI, S.; DOBASHI, K.; FUJIMOTO, S.; TANAKA, K.; SUZUKI, M.; TERASHIMA, Y.; HASUMI, K.; AKIYA, K.; NEGISHI, Y. and TAMAYA, T. A late phase II study of CPT-11 in gynecologic cancers. Research groups of CPT-11 in gynecologic cancers. Japanese Journal of Cancer and Chemotherapy, August 1991, vol. 18, no. 10, p. 1681-1689.

TIWARI, V.; SINGH, B.D. and TIWARI, K. N. Shoot regeneration and somatic embryogenesis from different explants of Brahmi [Bacopa monniera (L.) Wettst.]. Plant Cell Reports, April 1998, vol. 17, no. 6-7, p. 538-543.

TWYFORD, C.T. and MANTELL, S.H. Production of somatic embryos and plantlets from root cells of the greater yam. Plant Cell, Tissue and Organ Culture, July 1996, vol. 46, no. 1, p. 17-26. 
WALL, M.E.; WANI, M.C.; COOK, C.E.; PALMER, K.H.; MCPHAIL, A.T. and SIM, G.A. Plant anti-tumor agents: I. The isolation and structure of camptothecin, a novel alkaloidal leukemia and tumor inhibitor from Camptotheca acuminata. Journal of the American Chemical Society, August 1966, vol. 88, no. 16, p. 38883890 .

WATASE, I.; SUDO, H.; YAMAZAKI, M. and SAITO, K. Regeneration of transformed Ophiorrhiza pumila plants producing camptothecin. Plant Biotechnology, 2004, vol. 21 , no. 5 , p. 337-342.

WELANDER, M. Plant regeneration from leaf and stem segments of shoots raised in vitro from mature apple trees. Journal of Plant Physiology, 1988, vol. 132, no. 6, p. 738744.

WENZEL, C.L. and BROWN, D.C.W. Histological events leads to somatic embryo formation in cultured petioles of alfalfa. In Vitro Cellular and Development Biology - Plant, 1991, vol. 27, p. 190-196.

ZHANG, Chun-Lai; CHEN, Dong-Fang; ELLIOTT, Malcolm C. and SLATER, Adrian. Thidiazuron-induced organogenesis and somatic embryogenesis in sugar beet (Beta vulgaris L). In Vitro Cellular and Development Biology - Plant, March 2001, vol. 37, no. 2, p. 305-310. 